\title{
THE REPRESENTATION OF TERRORISM IN THE PUBLIC OPINION - FIXING THE IMAGES IN THE PUBLIC MENTALITY Daniel PÎSLARIU
}

\author{
“Carol I" National Defence University, Bucharest, \\ pislariu.daniel@myunap.net
}

\begin{abstract}
In the XXI century terrorism has become one of the most used terms in media, acquiring a global recognition. This is possible because of the heightened activity of various terrorist organizations in different geographical areas around the world starting from the tragic event who took place in the U.S.A. in 11.09.2001.

In addition to these issues is the desire of media to broadcast news of considerable interest to the public. Therefore one of the most suitable terms that suits both media and public requirements is terrorism.

So, mostly because of media, it seems that is possible that a person who doesn't know much about terrorism, even a sentence close to a definition of the term, knows that terrorism is a mixture of fear, politic, deaths and violence, which is true. Interesting fact is how the public is able to recognize terrorism and its form of manifestation because of media and how media generates representation of terrorism and fix them in the public mental.
\end{abstract}

\section{Keywords: terrorism, public opinion, media, images and representation}

\section{New media}

In the beginning of this article I will like to introduce you to a new concept of media, and that is the new-media. This is necessary because to understand the social images that media forms in generally and the image that attributes to terrorism especially, we must stop and analyze the mechanism by which the new media uses to fix these images in our mentality.

Today we are witnessing the accelerating evolution of mass-media, technologies, thus the globalization of the world [1]. Due to this evolution current, the way that people live, interact with each other and even the way that we see the world that surrounds us is being done by different mechanisms, in different steps.

The change that occurs in the mass-media sphere are mainly the result of the accelerated evolution in terms of technologies and of course the information that today is mostly easier to absorb by the public and which attracts the public opinion attention. These aspects can be defined as the transformation of the mass-media field. This transformation of the media sphere is based on the results of the low level of satisfaction delivered to the public, the innovation of the technological field and the new forms of communication through which the transmitter can become the receiver and vice versa.

This transformation of media also includes replacing the traditional part with a digital one. It is easy to observe the growth and the importance of the internet among newspapers and magazines.

Besides these notions, the new media comes with the capacity of transmitting information all over the world instantly. 
And because of this main aspect, massmedia uses it to spread news that has a powerful impact over the public to attract their attention.

To sum up with, the new-media represent a new stage, an upgrade of the traditional media. This transformation came because of the necessities of the public opinion which were not fulfilled. These necessities of the public can be described in one simple but also complex word: information.

\section{Mass-media and the social images}

In the first chapter we have spoken about the new media, or better said the new form that media is taking due to the technological evolution and the great amount of information that is necessary to transmit to the public.

Nowadays, mass-media represent all the technologies means through mass communications is being done and through which it reaches a large audience [2]. Due to the importance that mass-media gained over time, because of its main characteristic, to inform the public opinion, we realize that mass-media represents an important amount of time in our daily routine. This is why in present, a person with a normal schedule spend about three hours a day watching TV. Besides these, nearly all of the time we are connected to information. It doesn't matter if we listen to the radio, read an article in the newspapers, or, if we are surfing on the internet. What is important to emphasize is that in nearly all of our time we are connected to the massmedia means [3].

Still, why is it so important for us to be permanently wrapped in this large amount of information and more than this, does this information reflects reality? Is mass-media the reflection of reality or does it simply creates another part, or let us say image of society? These questions represent one of the most debated issues in the scientific exploration of the relationship between mass-media and society [4].

The necessity of this amount of information lies in the importance of it. It well known that information represents power. So, as we move on we realize that we need information to understand what exactly is going on whit our environment. We need information today as much as we need other needs which are situated at the base of the pyramid of Maslow.

Beside this, we consume information not only to be permanently informed about the latest event that took place, but also, we enjoy to do it because, another role that mass-media is playing is for entertainment. So, much of us, after a hard day we relax watching T.V. or surfing through the internet. Not just to search for fresh information, but to break out of the daily routine.

In search for new information the public is not aware that mass-media is generating more information than in needed. For example, think about the numbers of T.V. channels that today a normal person has access to. To continue with this idea, think about the growth of the internet.

In the moment when a great amount of information in being presented to us, the human brain tries to absorb this amount of it and when the information is being represented to fast, through the media mechanisms, we use to consider much of it true, without the questioning its truthfulness. This is called the ,ugly world" syndrome.

In search of the public opinion for information that shocks, most of the news gives priority to information that describes actions that are related to crimes, accidents, war, natural disasters, terrorist attack and others. The more a person consumes a larger quantity of information which is distributed by mass-media means, the more that person construct in his mentality a darker image of world [5].

So, is it possible that mass-media can create or shape the image of reality and insert into out mental another image of it? Because of the time that a person spends in front of the T.V. or surfing the internet, the images that he sees are not created by the brain. These images are created by an electronic device and directly inserted into the person 
mentality. In other words we do not participate at the development of these images. More than this, these images that are shown for a person are the same for all the public that is watching the same T.V. program, that in listening to the same radio frequency or surfing the same internet page [6].

As it seems, mass-media can shape and create another image of the society. Through its means, mass-media can create social images.

Social images represent cognitive assemblies composed of themes, principles and rules that represent a unitary character influencing norms and values circulating in society [7]. These social images can be described as vision of the world based on which the individual or a group of individuals can understand or interpret reality.

The process through social images are formed is called materialization [8]. The process is a complex one. Based on the information that mass-media is distributing towards the public it forms a number of concepts, reproducing this notion into an iconic plan. In other words, over the pressure of the great amount of information, the public simplify and absorbs the information as it is, creating a set of images on the mental scale.

The process of materialization has four essential steps. In the first one, through the means of mass-media, it is created a concept that in the next steps will be transformed into a social image. The second step consist in the selection of the information which is the concept described in the first step. In the second step the individual or the groups select the information that is consider to be useful. The third step consists in absorbing and forming on the level scale the social image. In this step it takes place the transformation from concept which is disguised as ordinary information to the future social image. At last, in the final step, on the individual mental, the social images are materialized in element of reality. In the last step, the social image is being crystallized on the individual mental level.

These images can differentiate form an individual to another. This in possible because every individual has its own beliefs that he is guiding through society. In addition to these, the experience that an individual has can affect the way that the social images are being reproduced in the mentality of him or her.

Nevertheless, it is possible that the representation of reality of an individual with some beliefs can transform and become as the same whit the majority. This majority is called the public opinion.

As we move on, we now can see that massmedia has an important role in our daily routine. Even if we want to select the amount of information that is being distributed to us, this process of selection can be hardly done. In need to stay informed and to create our own personal reality through we can understand the society, we are liable to construct and understand the reality with the information that was given to us by media.

\section{The image of terrorism in the public sphere}

In the search for new and shocking information, individuals have given their feed-back to the mass-media means, showing them exactly what kind of news have an important impact over them.

Therefor it is easy to observe why news headlines that containing elements related to war, economic collapse or terrorist attack enjoy a high audience. In this chapter I will like to explain and demonstrate how exactly the image of terrorism is being modified in the public sphere. More than this, even if we speak of the same phenomenon, it might surprise us that for some of us terrorism is a harmful phenomenon, while for others terrorism represents the will of the divinity.

Terrorism is today one of the most discussed terms in the international security councils. Even if does not have an internationally agreed definition, terrorism consist in a set of violent acts intended to create a wave a terror or fear over the 
population, perpetrated for a religious, political or ideological goal [9].

But the pronounced discussion over this topic are because of the threat itself, that terrorism represents over the international and national security of the states, or is it because there is being done to much media coverage over this known phenomenon?

Between mass-media and the terrorism phenomenon there is a strong link. Because of the great interest that the terrorism generates over the public opinion and because of this interest the profit increases in the domain of media, mass-media consider terrorism an opportunity to attract the desired attention and of course to increase they economic status. Because a terrorist attack represent a mixture of many aspects that make this phenomenon a very attractive subject, mass-media uses the element of drama, blood, human tragedy, danger, shocking footage and other words similar to these to increase the effect of the attack [10].

While mass-media is broadcasting the results after a terrorist attack took place, the terrorist organization which is responsible for the bombing is enjoying to observe that the wave of terror is being carried out by the means of media. It is easy to see that after a terrorist attack mass-media means fulfills the terrorists goals which are not only to record a number of victims or to destroy the representative monuments, and by broadcasting the result of the terrorists attack, the economic status of the media increases.

Beside these, by broadcasting news about terrorism media also creates in the public sphere a set of images regarding terrorism.

For example, after the several debates about a terrorist attack during a T.V. channel, a social image of this phenomenon is being formed and implemented to the individuals who are watching this channel. They see terrorism in the way that it is represented by the media mean through its specific mechanisms.

Most of the debates that took place in media and that are focused over terrorism usually contain terms like: hostage situation $80 \%$, assassinations $75 \%$, bombing $75 \%$, kidnappings $70 \%$, sabotage $60 \%$, torture $45 \%$ and hijackings in order to escape $35 \%$ [11].

As we can see, the public image that is inserted in the public mental about terrorism nowadays represents a mixture of the terms that we mention above. It is quite clear how a person can easily describe this phenomenon with a few words.

Using this terms on T.V. channels, on radio shows or on internet publishing creates in the public sphere the image that terrorism phenomenon rejoice today. This image of terrorism is due to the broadcasting of it. If we may question ourselves, what had happened it we didn't receive such information about terrorism? Did we still have had the same view over it? Surprisingly no, because, as I mentioned before, the public sphere is being shaped by the images that are created and distributed to the mental of the public. More of it, the repetitiveness of broadcasting of a terrorist attack does nothing more than to solidify the image of terrorism in the mental of the public.

As we can see, the representation of the terrorist phenomenon in the public opinion is based on the images that media constructs and offers to the public sphere. It is easy to observe that the more a person sped time absorbing information from the media the more his images over terrorism in specially and society in general are being shape not by himself but by the means of media.

These images over terrorism can differentiate starting from the beliefs, religion and cultural leanings of each individual. This is why from most of the western audience terrorism are criminals that use bombings to destroy the security stability into an area and to implement a wave of fear over the civilians. But for Islam audience we might be surprised that in some cases the terrorist image can be different turning into a fighter for freedom against the cultural occupation of the 
western side. This duality of the image that terrorism is having is a clear one. A person can be on one side or another. It depends on what information he is absorbing and what are his beliefs and cultural inclination.

\section{Conclusion}

To sum up, the image that terrorism has in present is due to the media coverage of each individual event that terrorist organization has.

After each terrorist attack, media means broadcast a great amount of information that describes the consequences of the bombing that took place. Base on this the public creates a set of images by means of which they can describe this phenomenon.
The representation of the terrorism in the public opinion is based on how much information is being broadcasted to the public sphere because when the amount of information is large, the credibility of it grows. It is nearly impossible to analyze and check the truthfulness of information when the rapidity of broadcasting it is pronounced.

Still, in some cases even if some of us have a different perspective over terrorism the public opinion makes its presence felt and force us to mix our image of the phenomenon with it. In any of the case, is it possible that our image of terrorism can be truly constructed by ourselves, without being affected by any external factors?

\section{References}

[1] Karol Jakubowicz, A new notion of media?, Council of Europe, 2009, p. 5

[2] http://en.wikipedia.org/wiki/Mass media, accessed at 13:43, 03.04.2015

[3] Senastian Bohler, 150 de experimente pentru a ințelege manipularea mediatică Psihologia consumatorului de mass-media, editura Polirom, București, 2009, p. 19

[4] Mieke Ceulemans, Guido Fauconnier, Mass-media: The image, role and social condition of women, The department of Communication, Science, Catholic University of Leuven, UNESCO, Paris, France, 1979, p. 5

[5] Senastian Bohler, 150 de experimente pentru a îțelege manipularea mediatică Psihologia consumatorului de mass-media, editura Polirom, București, 2009, p. 20

[6] Idem, p. 21

[7] Mihai Curelaru, Reprezentări Sociale, editura Polirom, București, 2006, p. 30

[8] Idem, p. 48

[9] http://en.wikipedia.org/wiki/Terrorism, accessed at 19:01, 03.04.2015

[10] http://www.e-ir.info/2012/07/22/terrorism-and-the-media-a-dangerous-symbiosis/, accessed at 19:38, 03.04.2015

[11] Olga Dănilă, Visarion Neagoe, Terorismul - o abordare psihologică, editura Militară, București, 2011, pag. 23-24

\section{Bibliography}

Karol Jakubowicz, A new notion of media?, Council of Europe, 2009

Senastian Bohler, 150 de experimente pentru a ințelege manipularea mediatică Psihologia consumatorului de mass-media, editura Polirom, București, 2009

Mieke Ceulemans, Guido Fauconnier, Mass-media: The image, role and social condition of women, The department of Communication, Science, Catholic University of Leuven, UNESCO, Paris, France, 1979

Mihai Curelaru, Reprezentări Sociale, editura Polirom, București, 2006

Olga Dănilă, Visarion Neagoe, Terorismul - o abordare psihologică, editura Militară, București, 2011

http://en.wikipedia.org/wiki/Mass_media

http://www.e-ir.info/2012/07/22/terrorism-and-the-media-a-dangerous-symbiosis/

http://en.wikipedia.org/wiki/Terrorism 